\title{
Clinical Features of Critical Congenital Heart Disease in Term Infants with Hypoxemia: A Single-Center Study in Korea
}

\author{
Eui Kyung Choi, Jeong Hee Shin, Gi Young Jang, and Byung Min Choi \\ Department of Pediatrics, Korea University College of Medicine, Seoul, Korea
}

\section{ABSTRACT}

Purpose: This study was performed to determine the clinical features of full-term infants with hypoxemia detected by pulse oximetry and to establish the diagnosis of critical congenital heart disease (CCHD).

Methods: We retrospectively reviewed the medical records of neonates who had been admitted to the neonatal intensive care unit within 2 weeks of birth at Korea University Ansan Hospital between January 2013 and October 2017 ( $n=450)$. We classified these neonates based on the presence of hypoxemia at admission and investigated neonatal characteristics, initial symptoms, echocardiographic findings, and final diagnosis associated with hypoxemic diseases.

Results: Of 450 term infants, 265 infants (58.9\%) were identified hypoxemia by pulse oximetry at admission. The most common symptoms of them were cyanosis and tachypnea. Among them, $80.1 \%$ of infants $(214 / 265)$ were diagnosed with respiratory tract disease and $8.3 \%$ of infants $(22 / 265)$ had congenital heart disease. Thirteen infants $(13 / 265,4.9 \%)$ had CCHD and were treated with urgent surgery or transcatheter intervention within 28 days of birth. Majority of infants with respiratory tract disorder were transferred from hospital immediately after birth, but $46.1 \%$ of infants (6/13) with CCHD remained asymptomatic after birth and were admitted after 48 hours after birth. In addition, other hypoxemic illnesses were identified as neonatal infectious and neurological diseases.

Conclusion: This study showed the importance of assessment in neonates with hypoxemia, including those diagnosed with CCHD. The possibility of CCHD should be considered in the differential diagnosis in neonates demonstrating hypoxemia after 48 hours of birth. A larger prospective study is needed to assess the effectiveness and outcomes of pulse oximetry for neonatal screening in Korea.

Key Words: Hypoxemia, Congenital heart disease, Oximetry, Newborn
Received: 26 April 2018

Revised: 21 May 2018

Accepted: 23 May 2018

Correspondence to: Byung Min Choi Department of Pediatrics, Korea University Ansan Hospital, Korea University College of Medicine, 123 Jeokgeumro, Danwon-gu, Ansan 15355, Korea

Tel: +82-31-412-6557

Fax: +82-31-405-8591

E-mail: cbmin@korea.ac.kr

Copyright(c)

By Korean Society of Neonatology.

All right reserved.

This is an Open-Access article distributed under the terms of the Creative Commons Attribution Non-Commercial License (http://creativecommons.org/licenses/ by-nc/4.0), which permits unrestricted non-commercial use, distribution, and reproduction in any medium, provided the original work is properly cited. 
서론

맥박산소측정법(pulse oximetry)은 경피적 혈액 산소포화도를 빠 르게 비침습적으로 측정할 수 있는 방법으로 신생아에서는 분만장, 신생아중환자실과 응급실에서 저산소혈증을 진단하는 데 주로 사용 되고 있다 ${ }^{1)}$. 맥박산소측정법은 사용 시 교정(calibration)이 필요 없 고, 단순히 신생아의 손이나 발에 부착하여 비침습적으로 그리고 지 속적으로 혈액 산소포화도 수치를 확인할 수 있고, 동맥혈 내 산소분 압을 잘 반영하므로, 중요한 활력 징후(vital sign)의 하나로 널리 활 용되고 있달.

출생 후 정상 만삭아의 시간 경과에 따른 혈액 산소포화도 수치는 출생 후 20-24시간 째까지 평균 97.8\%까지 상승하게 되며, 이후 그 수치를 계속 유지하는 것으로 보고 되고 있다 ${ }^{3,4)}$. 비록 건강한 만삭 아에서도 출생 초기에는 수면이나 수유 시에 주기적인 산소포화도 의 저하(desaturation)를 간혹 관찰할 수는 있으나, 만삭아에서 지속 적인 산소포화도의 저하 즉 저산소혈증(hypoxemia)이 있을 경우에 는 그 원인에 대한 철저한 규명이 필요하다 ${ }^{3)}$. 선천심질환은 흔히 나 타나는 선천적 결함 중 하나로서 유아 사망의 주요 원인이 되고 있다 5-7). 특히 중증 선천심질환(critical congenital heart disease, CCHD) 은 출생 초기인 신생아기부터 생명을 위협하는 심각한 증상이 나타 나는 경우로, 적절한 시기에 수술이나 카테터를 이용한 중재적 시술 이 꼭 필요한 질환으로 선천심질환 중 약 $25 \%$ 를 차지하고 있다 ${ }^{8,9}$. 이들 대부분은 동맥관 의존성 선천심질환들로서, 동맥관이 폐쇄되 면서 대동맥의 혈액 산소포화도를 현저히 감소시키거나 대동맥 혈 류량의 심각한 감소를 유발할 수 있으며, 이러한 변화가 급격히 진행 하여 사망에 이를 수 있으므로 조기 발견 및 신속한 진단을 통한 적 절한 치료가 요구되고 있다.

본 연구는 단일 기관의 후향적 연구로서, 신생아중환자실에 입원 시 맥박산소측정법으로 저산소혈증이 확인된 만삭 신생아를 대상으 로 그 원인 질환들을 분석하고, 특히 발견된 $\mathrm{CCHD}$ 의 임상적 특성을 알아보고자 하였다.

\section{대상 및 방법}

\section{1. 대상}

2013년 3월부터 2017년 10월까지 고려대학교 의료원 안산병원 신 생아중환자실에 입원한 재태 주령 37주 이상의 만삭아 중, 외부에서 출생하여 출생 후 2 주 이내에 전원 된 신생아 1,146 명을 대상으로 하 였다.

또한, 본 연구의 목적상, 심장질환의 동반 여부를 확인할 수 없었 던 심장 초음파 검사를 시행하지 않았던 환아는 제외하였고 따라서 총 450 명이 연구 대상이 되었다.

\section{2. 방법}

대상 환아의 의무기록지를 분석하여 인구 통계적 특성인 임신 주 수, 출생 체중, 성별 비, 분만 방법, 출생 후 입원까지의 경과 시간, 전 원 사유, 입원 시 증상, 입원 후 첫 6시간 동안의 산소포화도, 산소 흡 입 치료 여부와 산소 농도, 침습적 또는 비침습적 인공호흡기의 사용 여부 및 종류, 심장 초음파 소견, 최종 진단명 등을 조사하였다.

\section{3. 정의}

저산소혈증은 환자의 손 혹은 발에 부착하여 맥박을 감지함으로 써 경피적 혈액 산소포화도를 측정해 내는 맥박산소측정법으로 그 값이 $95 \%$ 미만인 경우로 정의하였다. 실제로 입원 후 6시간 동안 산 소포화도가 한 번이라도 $95 \%$ 미만의 값을 보였거나 혹은 $95 \%$ 이상 을 유지하기 위해 산소 투여나 호흡기 보조가 필요하였던 경우도 저 산소혈증이 있는 환아로 정의하였다.

저산소혈증의 원인 질환으로 최종 진단은 의무기록을 참고하여 영상의학 검사, 심장 초음파 검사 등 가능한 객관적인 근거로 판단하 였으며, 다른 진단과 중복되었을 경우에는 저산소혈증에 대한 기여 도에 따라 한 명의 임상의가 판단하여 분류하였다. 대표적인 신생아 질환의 정의는 다음과 같이 하였다.

신생아 호흡곤란증후군(respiratory distress syndrome, RDS)은 호 흡곤란 증후를 보이며 흥부 방사선 소견상 양측 폐야에 미만성 과 립상 음영 증가, 공기 기관지 음영 등을 보이면서, 흡기산소 농도가 0.4 이상 요구되어 폐 표면 활성제(surfactant)의 치료가 필요한 경 우로 정의하였다. 신생아의 일과성 빠른호흡(transient tachypnea of newborn, TTN) 또는 신생아의 호흡곤란증(respiratory distress, $\mathrm{RD})$ 은 출생 후 호흡곤란 증후를 보이면서, 흥부 방사선 사진에서 는 양측 폐문 부위 햇살 모양의 소견을 보이거나, RDS 또는 태변 흡 입 증후군(meconium aspiration syndrome, MAS)과 구분되는 방사 선 소견을 보이는 경우, 태변이나 감염, 선천성 기형 등 다른 호흡 곤란의 원인이 없는 경우로 정의하였다 ${ }^{10)}$. MAS는 출생 시 태변 착 색이 있어야 하고, 호흡곤란 증상이 있으면서 흥부 방사선 검사에 서 미만성의 비대칭적인 고르지 못한 침윤이 있는 경우로 정의하였 다 ${ }^{11}$. 폐 외 공기 누출(extrapulmonary air leaks)은 기흉, 심막기종, 피하기종, 종격동기종, 폐사이질기종 등이 포함되었다. 선천 폐렴 (congenital pneumonia)은 호흡곤란 증상이 있고 흥부 방사선 소견 상 폐 침윤, 폐 음영 증가 소견이 보이고 다음의 다섯 가지 조건 중에 서 두 가지 이상 동반된 경우로 정의하였다: (1) 패혈증의 임상적인 증상, (2) 18 시간 이상의 조기양막파수 또는 분만 전 산모의 $38^{\circ} \mathrm{C}$ 이 상의 발열, (3) 혈액 검사 소견상 $<4 \times 10^{3} / \mathrm{mm}^{3}$ 또는 $>20 \times 10^{3} / \mathrm{mm}^{3}$ 의 백혈구치, $0.03 \mathrm{mg} / \mathrm{dL}$ 이상 C-반응단백질(C-reactive protein) 의 증가 소견, (4) 혈액 배양 검사에서 균이 동정, (5) 기관 흡인 객 담 배양 검사에서 균이 동정 ${ }^{10)}$. 신생아 경련, 대사 이상 질환(inborn error of metabolism), 저산소성 허혈성 뇌증(hypoxic ischemic 
encephalopathy, HIE), 저긴장 아기 증후군(floppy baby syndrome) 은 신생아 신경계 질환으로 분류하였다. $\mathrm{HIE}$ 는 병력과 두부 영상 검 사 소견, Sarnat와 Sarnat ${ }^{12)}$ 에 의한 임상적 단계를 바탕으로 진단하였 다.

선천성 심질환은 Mitchell 등히이 제시한 정의를 사용하였으며 단 독 심장 부정맥, 심근질환, 단독 이첨 대동맥판막, 역류가 없는 승모 판 탈출, 생리적인 폐동맥 협착, 심장 종양은 제외되었다. 선천성 심 질환의 진단은 소아 심장 분과 전문의에 의한 심장 초음파 검사로 이 루어졌으며 다음과 같이 세분하였다.

CCHD는 생후 28일 이내에 생명유지를 위해 수술적 치료나 카테 터 중재 시술이 필요했던 심장질환으로 대혈관 전위(transposition of the great arteries), 폐동맥 폐쇄(pulmonary atresia), 좌심 형성부 전 증후군(hypoplastic left heart syndrome), 대동맥궁 단절(interrupted aortic arch), 대동맥 축착(coarctation of the aorta, CoA) 과 같은 질병이 포함되었다 ${ }^{8)}$. Significant congenital heart diseases (CHDs)는 심장 기능에 영향을 미치나 생후 초기에 생명에 지장을 주는 경우는 드물고 빠른 치료나 중재가 필요 없는 심장질환으로 증 상이 있는 심실중격결손(ventricular septal defect, VSD), 심방중격결 손(atrial septal defect, ASD), 동맥관개존증(patent arteriosus), 완전 방실중격결손(complete atrioventricular defect, AVSD), 폐동맥혈의 흐름이 유지되는 팔로네징후(tetralogy of Fallot)와 같은 질병이 포함 되었다. Simple CHDs는 생후 2개월 이상 지속되나 증상이 없고 개 입이 필요 없는 심장질환으로 작은 $\mathrm{VSD}$ 나 $\mathrm{ASD}(<3 \mathrm{~mm})$, 난원공개 존(patent foramen ovale), 말초 폐동맥 협착(peak flow velocity $\leq$ $2.0 \mathrm{~m} / \mathrm{sec}$ )과 같은 질병이 포함되었다. 하지만 simple $\mathrm{CHD}$ 는 저산 소혈증의 원인 질환으로 분류할 수 없으므로 본 연구에서 이러한 동 반 질환으로 분류하지 않고 무시하였다 ${ }^{14)}$.

본 연구는 고려대학교 안산병원 기관생명윤리위원회의 승인(IRB no. AS17135-002)을 받았다.

\section{결과}

\section{1. 대상 환아들의 임상적 특징}

본 연구에 포함된 환아는 총 450 명이었으며, 이 중 신생아중환자 실 입원 당시 저산소혈증이 있는 대상 환아로 정의된 경우는 265 명 (58.9\%)이었다. 대상 환자 265명의 평균 재태 주령은 39.0土1.0주, 출생 체중은 $3,308 \pm 457 \mathrm{~g}$ 이었다. 남아는 119 명(45.0\%)이었고, 제왕 절개분만이 174 명(65.9\%)이었다(Table 1).

\section{2. 입원 시의 주요 동반 징후 및 증상}

입원 시 저산소혈증과 동반된 주요 징후 및 증상으로는 청색증이 가장 높은 빈도로 $56.6 \%(150 / 265)$ 에서 동반되었다. 그 다음으로는
빠른 호흡, 흥부 함몰, 호기 시 신음, 무호흡과 같은 호흡곤란 증상을 동반하는 경우가 많았으며 이외에는 심 잡음, 처짐, 느린맥/빈맥, 경 련, 열, 수유 불가능, 저혈당 등이 있었다(Table 2).

\section{3. 저산소혈증의 원인 질환}

저산소혈증의 원인 질환으로는 호흡기계 질환(80.1\%), 심혈관계 질환(8. $3 \%)$, 신경계 질환 $(5.7 \%)$, 감염 질환 $(2.3 \%)$, 기타 순이었다 (Table 3)

호흡기 질환으로는 TTN 또는 RD가 109명(41.1\%)으로 가장 많았 으며 RDS 41명(15.5\%), MAS 41명(15.5\%), 폐 외 공기 누출 18명(6.8 $\%)$ 순이었다. 심혈관계 질환은 총 22 명(8.3\%)에서 발견되었는데 그 중 $\mathrm{CCHD}$ 를 진단받은 경우는 13 명으로 전체 저산소혈증 환자의 $4.9 \%$ (13/265)였으며 significant $\mathrm{CHD}$ 는 3.4\% (9/265)이었다.

출생 후 48시간 이내에 입원한 저산소혈증 환자는 전체 환자의 90.2\% (239/265)로 신생아 호흡기계 질환이 대부분이었으며, 특히 $\mathrm{RDS}, \mathrm{MAS}$, 폐 외 공기 누출, 선천성 폐렴의 경우는 모두 48시간 이내 에 입원하였다. 48시간 이후에 입원한 저산소혈증 환자 중 심혈관계

Table 1. Clinical Characteristics of the Study Population $(\mathrm{n}=$ 265)

\begin{tabular}{lc}
\hline Characteristic & Value \\
\hline Gestational age (wk) & $39.0 \pm 1.0$ \\
Birth weight (g) & $3,308 \pm 457$ \\
Male sex & $119(45.0)$ \\
Caesarean section & $174(65.9)$
\end{tabular}

Values are expressed as mean \pm standard deviation or number of infants (\%).

Table 2. Initial Symptoms and Signs of Neonates Included in the Study

\begin{tabular}{lc}
\hline Initial symptoms and signs* & No. of infant (\%) \\
\hline Cyanosis & $150(56.6)$ \\
Tachypnea & $112(42.3)$ \\
Chest retraction & $98(37.0)$ \\
Moaning sound & $63(23.8)$ \\
Murmur & $13(5.0)$ \\
Apnea & $11(4.1)$ \\
Lethargy & $7(2.6)$ \\
Bradycardia/Tachycardia & $5(1.9)$ \\
Seizure & $2(0.8)$ \\
Fever & $1(0.4)$ \\
Poor oral intake & $1(0.4)$ \\
Hypoglycemia & $1(0.4)$ \\
Laboratory abnormality & $3(1.1)$
\end{tabular}

*Multiple responses available. 
Table 3. Final Disease Categorization in Neonates who Demonstrated Hypoxemia upon Admission*

\begin{tabular}{|c|c|c|c|}
\hline Variable & $<2$ wk of birth (total $n=265$ ) & $<48 \mathrm{hr}(\mathrm{n}=239)$ & $48 \mathrm{hr}$ to $2 \mathrm{wk}(\mathrm{n}=26)$ \\
\hline Respiratory disease & $214(80.1)$ & $208(87.0)$ & $6(26.0)$ \\
\hline TTN or RD & $109(41.1)$ & $104(43.5)$ & $5(19.2)$ \\
\hline RDS & $41(15.5)$ & $41(17.2)$ & \\
\hline MAS & $41(15.5)$ & $41(17.2)$ & \\
\hline Extrapulmonary air leak & $18(6.8)$ & $18(7.5)$ & \\
\hline Congenital diaphragmatic hernia & $3(1.1)$ & $2(0.8)$ & $1(3.8)$ \\
\hline Congenital pneumonia & $2(0.7)$ & $2(0.8)$ & \\
\hline Cardiovascular disease & $22(8.3)$ & $11(4.6)$ & $11(42.3)$ \\
\hline Critical congenital heart disease & $13(4.9)$ & $6(2.5)$ & $7(27.0)$ \\
\hline Significant congenital heart disease & $9(3.4)$ & $5(2.1)$ & $4(15.4)$ \\
\hline Neurological disease & $15(5.7)$ & $10(4.2)$ & $5(19.2)$ \\
\hline HIE & $9(3.4)$ & $8(3.3)$ & $1(3.8)$ \\
\hline Neonatal seizure & $3(1.1)$ & & $3(11.5)$ \\
\hline Floppy infant & $2(0.8)$ & $1(0.4)$ & $1(3.8)$ \\
\hline Dandy walker syndrome & $1(0.4)$ & $1(0.4)$ & \\
\hline Infectious disease & $6(2.3)$ & $3(1.3)$ & $3(11.5)$ \\
\hline Digestive tract disease & $3(1.1)$ & $3(1.3)$ & \\
\hline Endocrine disease & $3(1.1)$ & $3(1.3)$ & \\
\hline Hematologic disease & $2(0.8)$ & $1(0.4)$ & $1(3.8)$ \\
\hline
\end{tabular}

Values are expressed as number of infants (\%).

*Intergroup comparison between neonates admitted within the first 48 hours of birth and those admitted 48 hours to 2 weeks of age.

Abbreviations: TTN, transient tachypnea of newborn; $\mathrm{RD}$, respiratory distress of newborn; RDS, respiratory distress syndrome; MAS, meconium aspiration syndrome; HIE, hypoxic ischemic encephalopathy.

질환이 $42.3 \%(11 / 26)$ 로 가장 많았고, 호흡기계 질환, 신경계 질환 순이었다(Table 3)

\section{4. 심혈관계 질환}

심혈관계 질환으로 분류된 22명은 모두 선천성 심질환이었으며 $\mathrm{CCHD}$ 는 13명, significant CHD는 9명이 있었다(Table 4). CCHD 환 자들의 특성을 살펴보면, 산전 검사를 정기적으로 받지 않은 산모에 게서 태어난 환자가 3 명 있었고 정기적인 산전 검사를 받은 10 명에 서도 출생 전에 선천성 심질환을 진단받은 경우는 없었다.

입원한 시기를 살펴보면, 산부인과 출생 후 신생아실에서 퇴원 전 에 전원 온 경우는 7명이었고, 이후 산후조리원에서 지내던 중 전원 온 경우는 2 명, 그 이후에 응급실을 통해 입원한 경우는 4 명이었다. $\mathrm{CCHD} 13$ 명에 대한 각각 환아들의 특성을 입원한 시간에 따라 살펴 보면, 출생 후 48 시간 이후에 입원한 경우가 7 명이었고 이 중 10 일 이후에 입원한 경우도 3명이었다(Table 5). 특히 CoA, 대동맥 판막 협착(aortic valve stenosis), 대동맥궁 단절과 같은 전형적인 청색증 형 심질환이 아닌 환자는 늦게 발견되고 있었다.
Table 4. Congenital Heart Diseases in Neonates with Hypoxemia

\begin{tabular}{lc}
\hline Classification & Number \\
\hline Critical congenital heart disease & 13 \\
PA-IVS & 3 \\
DORV, Taussing-Bing anomaly & 1 \\
TGA & 2 \\
Truncus arteriosus & 2 \\
CoA & 1 \\
PS & 1 \\
AS & 1 \\
IAA & 2 \\
Significant congenital heart disease & 9 \\
VSD (large and medium) & 6 \\
AVSD & 2 \\
PDA & 1
\end{tabular}

Abbreviations: PA-IVS, pulmonary atresia with intact ventricular septum; DORV, double outlet of right ventricle; TGA, transposition of the great arteries; CoA, coarctation of the aorta; PS, pulmonary stenosis; AS, aortic valve stenosis; IAA, interrupted aortic arch; VSD, ventricular septal defect; AVSD, atrioventricular septal defect; PDA, patent ductus arteriosus. 
Table 5. Clinical Characteristics of Neonates with Critical Congenital Heart Disease

\begin{tabular}{|c|c|c|c|c|c|c|c|}
\hline CCHD lesions & $\begin{array}{l}\text { Age at } \\
\text { referral } \\
\text { (hr) }\end{array}$ & $\begin{array}{c}\text { GA } \\
\text { (wk) }\end{array}$ & $\begin{array}{c}\text { Birth } \\
\text { weight }\end{array}$ & $\begin{array}{c}\text { Initial } \\
\mathrm{SpO}_{2}\end{array}$ & Symptoms & $\begin{array}{c}\text { Antenatal } \\
\text { ultrasonograms }\end{array}$ & Management \\
\hline PA-IVS & 2 & $38^{+2}$ & 3,000 & 70 & Cyanosis, murmur & Normal & Balloon valvuloplasty \\
\hline TGA & 2 & $38^{+2}$ & 3,000 & 85 & Cyanosis & Normal & Atrial septostomy \\
\hline TGA & 2.5 & $38^{+0}$ & 2,940 & 82 & Cyanosis & Normal & Transfer \\
\hline DORV, Taussing-Bing anomaly & 7 & $38^{+5}$ & 3,460 & 84 & Cyanosis & Normal & Transfer \\
\hline PA-IVS & 10 & $38^{+6}$ & 2,780 & 72 & Cyanosis & Normal & Rastelli operation \\
\hline Truncus arteriosus & 10 & $39^{+0}$ & 3,120 & 90 & Poor oral intake & Normal & Transfer \\
\hline PS & 72 & $38^{+3}$ & 3,420 & 81 & Tachypnea, cyanosis, murmur & No prenatal care & Transfer \\
\hline IAA & 153 & $39^{+0}$ & 3,200 & 70 & Cyanosis & Normal & PDA stent \\
\hline Truncus arteriosus & 167 & $39^{+0}$ & 3,200 & 92 & Tachypnea, chest retraction, murmur & No prenatal care & Transfer \\
\hline IAA & 169 & $38^{+6}$ & 2,800 & 85 & Cyanosis, murmur & No prenatal care & PDA stent \\
\hline CoA & 240 & $38^{+2}$ & 2,430 & 70 & Cyanosis, murmur, lethargy & Normal & Repair operation \\
\hline AS & 258 & $40^{+1}$ & 3,030 & 90 & Tachypnea, murmur & Normal & Balloon valvuloplasty \\
\hline PA-IVS & 290 & $40^{+1}$ & 3,900 & 40 & Cyanosis & Normal & Shunt operation \\
\hline
\end{tabular}

Abbreviations: CCHD, critical congenital heart disease; GA, gestational age; PA-IVS, pulmonary atresia with intact ventricular septum; TGA, transposition of the great arteries; DORV, double outlet of right ventricle; PS, pulmonary stenosis; PDA, patent ductus arteriosus; IAA, interrupted aortic arch; CoA, coarctation of the aorta; AS, aortic valve stenosis.

고찰

본 연구에서 단일기관에서 출생 후 2 주 이내에 신생아집중치료실 로 입원한 만삭아 중 맥박산소측정법으로 저산소혈증이 확인된 경 우는 $58.9 \%$ 로 많은 빈도를 보이고 있었다. 저산소혈증의 원인 질환 으로 호흡기계 질환이 $80 \%$ 정도로 가장 많았으나, 심혈관계 질환도 $8.3 \%$ 를 차지하고 있었다. 심혈관계 질환은 모두 선천성 심질환으로 신속한 진단과 처치가 필요한 CCHD가 60\% 정도를 차지하고 있었 다.

맥박산소측정법을 이용한 혈액 산소포화도 감시는 과산소혈증 을 반영하지는 못하지만, 저산소혈증을 발견하는 데는 매우 유용 하다 ${ }^{15)}$. 저산소혈증이 있는 경우 청색증을 보일 수 있는데, 육안으 로 청색증을 구분하려면 혈액 내에 환원혈색소(deoxygenated or reduced hemoglobin)가 3-5 g/dL 이상이 되어야 한다. 따라서 경 미한 저산소혈증이 있는 신생아는 동맥혈 산소포화도가 80\%-95\% 인 경우에는 육안으로 청색증이 관찰되지 않을 수 있다 ${ }^{16}$. 따라서 저 산소혈증을 확인하기 위해서는 맥박산소측정법을 이용하여야만 한 다.

대부분의 CCHD는 신생아 시기에 청색증이 나타나기 전에 어느 정도의 저산소혈증을 보이므로 ${ }^{17} 1990$ 년대 연구에서부터 신생아 신 체 검진을 보완하는 수단으로서의 맥박산소측정기를 CCHD의 선별 검사로 제안하기 시작하였다 ${ }^{18)}$. 이는 출생 후 일정한 시간에 맥박산 소측정기로 신생아의 상지와 하지에서 경피적 혈액 산소포화도를 측정하는 것을 말한다. 2011년부터는 본격적으로 산소포화도 측정
이 신생아에게 추천되었고 관련된 많은 선별 검사 지침에 대한 연구 가 이루어졌다. 선별 검사 시기, 차단치 (cut-off value), 측정하는 신 체 부위에 대해서는 각 연구마다 지침이 조금씩 달랐으나 산소포화 도 측정은 유용한 선별 검사 도구라는 결론을 얻을 수 있었다 ${ }^{19}$. 대 규모 연구결과를 바탕으로 ${ }^{8,20-22)}$ 2011년 미국에서는 CCHD를 조기에 진단하기 위한 맥박산소측정법을 이용한 선별 검사를 '권장하는 선 별 검사 패널(Recommended Uniform Screening Panel, RUSP)'에 추 가하였으며 현재 미국의 대부분의 병원에서 신생아들을 대상으로 $\mathrm{CCHD}$ 선별 검사를 시행하고 있다 ${ }^{23-25)}$. 이 선별 검사법은 생후 출생 후 24-48시간 또는 24시간 이내에 퇴원할 경우 퇴원 직전에 시행하 게 되어 있으며 (1) 손과 발 어디에서든 산소포화도가 < $90 \%$ 인 경우, (2) 손과 발에서 1 시간 간격을 두고 3 번 측정하였을 때 모두 산소포 화도가 $\langle 95 \%$ 인 경우, (3) 오른손과 하지에서 1시간 간격을 두고 3 번 측정하였을 때 그 값의 차이가 $>3 \%$ 인 경우 중 하나라도 해당될 경우 양성으로 판단한다 ${ }^{23,24)}$.

하지만, 국내에서는 맥박산소측정을 이용한 CCHD 선별 검사가 국가적으로 제도적으로 시행되지 않고 있다. 또한 CCHD에 대한 정 확한 유병률 및 치료에 대한 역학 연구가 많이 부족하다. 반면, 우리 나라는 다른 나라에 비해 산전에 태아 초음파 검진의 횟수가 많으며 출산율 감소와 더불어 선천성 심질환의 발생률이 출생아 1,000 명 당 $2.4 \%-3.8 \%$ 로 낮아 ${ }^{26)}$ 신생아실에서 CCHD의 선별 검사로 산소포화 도 측정을 하는 것이 얼마나 유용할지 에 대한 논의가 필요하겠다.

맥박산소측정법을 이용한 CCHD 선별 검사의 일차 목적은 CCHD 환자를 조기 발견하는 데 있지만, 저산소혈증이 있는 신생아들에게 
서 패혈증, 선천성 폐렴, 신생아 폐질환에 동반된 폐동맥 고혈압 지 속증과 같은 심질환 이외의 life-threatening condition이 확인되는 비 율이 $0.6 \%$ 정도로 보고되고 있어 이러한 질환에서도 환자의 상태가 악화되기 전에 조기에 발견하고 치료함으로써 예후의 개선을 기대 해 볼 수 있다 ${ }^{27,28)}$. 본 연구에서도 맥박산소측정법으로 저산소혈증 이 확인된 만삭 신생아에서 다양한 원인 질환을 발견하였으며 특히 호흡기계 질환이 $80 \%$ 정도로 가장 많았다.

연구의 제한점으로는 신생아집중치료실 입실 당시 맥박산소측 정법으로 시행한 값이 양측 상하지 중 일관된 부위에서 측정된 값 이 아니고 각각의 다른 의료 기관들에서 산소 치료를 받으면서 온 경 우를 포함시켜 실제 저산소혈증이 있는 환자보다 더 많은 수가 포 함되었을 가능성이 있다. 또한, 산소 치료 대신 양압의 호흡기 보조 가 필요한 환자를 구분하지 못하여 $\mathrm{VSD}, \mathrm{AVSD}$ 와 같은 비청색증형 significant CHD 환자가 포함되었다. 그러나 본원 입원 후 6시간 동 안의 4 번의 산소포화도 값과 호흡 보조 요법, 산소치료 유무를 기록 하고 평가하여 확대 진단의 오류를 줄이고자 하였다. 또한, 본 연구 는 후향적인 연구로 환자들의 정확한 저산소혈증의 발생 시기는 알 수 없으며 입원까지 경과 시간을 조사하여 분석하였다.

본 연구는 단일기관의 연구로 출생 후 전원 오는 신생아에 대한 처 치 및 진단, 치료에 있어서 일관성을 유지하였다. 출생 후 2 주 이내 에 신생아집중치료실로 입원한 만삭아 중 맥박산소측정법으로 저 산소혈증이 확인된 경우의 $8.3 \%$ 에서 심혈관계 질환이 발견되었으 며 이들 모두는 선천성 심질환으로 신속한 진단과 처치가 필요한 $\mathrm{CCHD}$ 가 $60 \%$ 정도로 절반 이상을 차지하고 있었다. 또한, 증상의 발현 이전에 선별 검사가 이루어지지 못하였으며, 특히 출생 후 10 일 이후에 발견이 되어 위중한 경과를 보인 경우도 있었다. 출생 직 후가 아닌 48시간 이후에 저산소혈증이 동반되어있을 경우 CCHD 를 감별하기 위해 심장 초음파 검사를 조기에 실시하는 것이 중요하 다고 볼 수 있겠으며 국내에서도 무증상 신생아를 대상으로 하는 맥 박산소측정을 이용한 $\mathrm{CCHD}$ 선별 검사의 도입을 고려할 필요가 있 겠다. 향후 우리 라의 실정에 맞는 선별 검사 제도를 만들기 위한 효 율성 및 비용 효과성에 대한 전향적인 연구를 통해 그 유용성의 확인 이 필요하겠다.

\section{REFERENCES}

1. Salyer JW. Neonatal and pediatric pulse oximetry. Respir Care 2003;48:386-96.

2. Mower WR, Myers G, Nicklin EL, Kearin KT, Baraff LJ, Sachs C. Pulse oximetry as a fifth vital sign in emergency geriatric assessment. Acad Emerg Med 1998;5:858-65.

3. O'Brien LM, Stebbens VA, Poets CF, Heycock EG, Southall DP. Oxygen saturation during the first 24 hours of life. Arch Dis
Child Fetal Neonatal Ed 2000;83:F35-8.

4. Levesque BM, Pollack P, Griffin BE, Nielsen HC. Pulse oximetry: what's normal in the newborn nursery? Pediatr Pulmonol 2000; 30:406-12.

5. Heron MP, Smith BL. Deaths: leading causes for 2003. Natl Vital Stat Rep 2007;55:1-92.

6. Rosano A, Botto LD, Botting B, Mastroiacovo P. Infant mortality and congenital anomalies from 1950 to 1994: an international perspective. J Epidemiol Community Health 2000;54:660-6.

7. Chung SH, Choi YS, Bae CW. Changes in the neonatal and infant mortality rate and the causes of death in Korea. Korean J Pediatr 2011;54:443-55.

8. Ewer AK, Middleton LJ, Furmston AT, Bhoyar A, Daniels JP, Thangaratinam S, et al. Pulse oximetry screening for congenital heart defects in newborn infants (PulseOx): a test accuracy study. Lancet 2011;378:785-94.

9. Talner CN. Report of the New England Regional Infant Cardiac Program, by Donald C. Fyler, MD, Pediatrics, 1980; 65(suppl):375-461. Pediatrics 1998;102(1 Pt 2):258-9.

10. Agrawal V, David RJ, Harris VJ. Classification of acute respiratory disorders of all newborns in a tertiary care center. J Natl Med Assoc 2003;95:585-95.

11. Dargaville PA, Copnell B; Australian and NewZealand Neonatal Network. The epidemiology of meconium aspiration syndrome: incidence, risk factors, therapies, and outcome. Pediatrics 2006;117:1712-21.

12. Sarnat HB, Sarnat MS. Neonatal encephalopathy following fetal distress. A clinical and electroencephalographic study. Arch Neurol 1976;33:696-705.

13. Mitchell SC, Korones SB, Berendes HW. Congenital heart disease in 56,109 births. Incidence and natural history. Circulation 1971;43:323-32.

14. Chung ML, Lee BS, Kim EA, Kim KS, Pi SY, Oh YM, et al. Impact of fetal echocardiography on trends in disease patterns and outcomes of congenital heart disease in a neonatal intensive care unit. Neonatology 2010;98:41-6.

15. Severinghaus JW, Honda Y. History of blood gas analysis. VII. Pulse oximetry. J Clin Monit 1987;3:135-8.

16. Lundsgaard C, Van Slyke D, Abbott ME. Cyanosis. Can Med Assoc J 1923;13:601-4.

17. Ainsworth S, Wyllie JP, Wren C. Prevalence and clinical significance of cardiac murmurs in neonates. Arch Dis Child Fetal Neonatal Ed 1999;80:F43-5.

18. Hoke TR, Donohue PK, Bawa PK, Mitchell RD, Pathak A, Rowe PC, et al. Oxygen saturation as a screening test for critical congenital heart disease: a preliminary study. Pediatr Cardiol 2002; 23:403-9.

19. Plana MN, Zamora J, Suresh G, Fernandez-Pineda L, Thangaratinam S, Ewer AK. Pulse oximetry screening for critical 
congenital heart defects. Cochrane Database Syst Rev 2018;3: CD011912.

20. Riede FT, Worner C, Dahnert I, Mockel A, Kostelka M, Schneider P. Effectiveness of neonatal pulse oximetry screening for detection of critical congenital heart disease in daily clinical routine: results from a prospective multicenter study. Eur J Pediatr 2010;169:975-81.

21. de-Wahl Granelli A, Wennergren M, Sandberg K, Mellander M, Bejlum C, Inganas L, et al. Impact of pulse oximetry screening on the detection of duct dependent congenital heart disease: a Swedish prospective screening study in 39,821 newborns. BM] 2009;338:a3037.

22. Thangaratinam S, Daniels J, Ewer AK, Zamora J, Khan KS. Accuracy of pulse oximetry in screening for congenital heart disease in asymptomatic newborns: a systematic review. Arch Dis Child Fetal Neonatal Ed 2007;92:F176-80.

23. Kemper AR, Mahle WT, Martin GR, Cooley WC, Kumar P, Morrow $W R$, et al. Strategies for implementing screening for critical congenital heart disease. Pediatrics 2011;128:e1259-67.
24. Centers for Disease Control and Prevention. Key findings: state actions to adopt newborn screening for critical congenital heart defects [Internet]. Atlanta: CDC; 2015 [cited 2018 May 24]. Available from: http://www.cdc.gov/ncbddd/heartdefects/ features/states-adopt-screening.html.

25. Mouledoux J, Guerra S, Ballweg J, Li Y, Walsh W. A novel, more efficient, staged approach for critical congenital heart disease screening. J Perinatol 2017;37:288-90.

26. Cho SY, Oh JH, Lee JH, Lee JY, Lee SJ, Han JW, et al. Recent incidence of congenital heart disease in neonatal care unit of secondary medical center: a single center study. Korean J Pediatr 2012;55:232-7.

27. Narayen IC, Blom NA, van Geloven N, Blankman EIM, van den Broek AJM, Bruijn M, et al. Accuracy of pulse oximetry screening for critical congenital heart defects after home birth and early postnatal discharge. J Pediatr 2018;197:29-35.e1.

28. Jawin V, Ang HL, Omar A, Thong MK. Beyond critical congenital heart disease: newborn screening using pulse oximetry for neonatal sepsis and respiratory diseases in a middle-income country. PLoS One 2015;10:e0137580. 